\title{
Autologous Dinitrophenyl Vaccine
}

National Cancer Institute

\section{Source}

National Cancer Institute. Autologous Dinitrophenyl Vaccine. NCI Thesaurus. Code C1982.

A vaccine consisting of autologous cancer cells modified with the hapten, Dinitrophenyl. The treatment program consists of multiple intradermal injections of irradiated DNPmodified autologous tumor cells mixed with bacillus Calmette-Guerin. 